\title{
POLA BAKTERI AEROB PADA DISPENSER AIR MINUM KEMASAN GALON PADA KONSUMEN DI KECAMATAN TIKALA KOTA MANADO
}

\author{
${ }^{1}$ Tri Sudradjat \\ ${ }^{2}$ Velma Buntuan \\ ${ }^{2}$ Fredine E. S. Rares
}

\author{
${ }^{1}$ Kandidat Skripsi Fakultas Kedokteran Universitas Sam Ratulangi Manado \\ ${ }^{2}$ Bagian Mikrobiologi Fakultas Kedokteran Universitas Sam Ratulangi manado \\ Email:Trisudrajat.100111032@gmail.com
}

\begin{abstract}
Refill drinking water in gallons require dispensers to make the water more practible to drink. Use of dispenser that makes the presentation be practical, but may menyembabkan gathering bacteria because of the lack of consumer attention to the cleanliness of the dispenser. Drinking water quality is poor mikrobiologisnya can cause disease, one of which is diarrhea. Necessary research or clinical testing in the laboratory to determine whether drinking water is contaminated or not. This study aimed to determine the pattern of aerobic bacteria in gallons of consumers in the District Tikala Manado. This was a descriptive study. Samples were taken from 20 gallons. Identification of bacteria was performed with culture. The results showed that Bacillus subtilis was found in 9 samples (27.27\%), Proteus vulgaris in 5 samples (16.66\%), Serratia rubidaea in 5 samples (16.66\%), Escherichia coli in 2 samples (6.66\%), Enterobacter cloacae in 2 samples (6.66\%), Streptococcus spp in 2 samples (6.66\%), Gram-negative diplococcus in 2 samples (6.66\%), Providencia stuartii in 2 samples (6.66\%), and Pseudomonas bacteria in 1 sample (3.33\%). Conclusion: In this study, the most frequently found bacteria was Bacillus subtilis
\end{abstract}

Keywords: water, dispenser, bacteria

\begin{abstract}
Abstrak : Air minum isi ulang dalam kemasan galon membutuhkan alat berupa dispenser sebagai alat untuk meletakan air minum kemasan galon. Penggunan dispenser inilah yang membuat penyajian menjadi praktis, akan tetapi bisa menyebabkan berkumpulnya bakteri karena kurangnya perhatian konsumen terhadap kebersihan dispenser. Air minum yang kualitas mikrobiologisnya buruk dapat menyebabkan penyakit, salah satunya diare. Diperlukan penelitian atau pengujian secara klinis di laboratorium untuk mengetahui apakah air minum terkontaminasi atau tidak. Penelitian ini bertujuan untuk mengetahui pola bakteri aerob pada dispenser air minum kemasan galon pada konsumen di Kecamatan Tikala Kota Manado. Penelitian ini menggunakan metode penelitian deskriptif. Sampel diambil dari 20 pengguna dispenser air minum kemasan galon di Kecamatan Tikala Kota Manado. Identifikasi bakteri dilakukan dengan media kultur. Hasil penelitian menunjukkan Bacillus subtilis sebesar 9 sampel (27,27\%), Proteus vulgaris 5 sampel (16,66\%), Serratia rubidaea 5 sampel ( 16,66\%), Escherchia coli 2 sampel (6,66\%), Enterobacter cloacae 2 sampel (6,66\%), Streptococcuspp 2 sampel (6,66\%), Diplococcusram negatif 2 sampel (6,66\%), Providencia stuartii 2 sampel (6,66\%), dan bakteri Pseudomonas 1 sampel (3,33\%). Simpulan: Pada penelitian ini jenis bakteri terbanyak ditemukan ialah Bacillus subtilis.
\end{abstract}

Kata kunci: air, dispenser, bakteri 
Air adalah senyawa yang sangat penting bagi mahkluk hidup di dunia ini. Termasuk manusia membutuhkan air setiap hari untuk minum, memasak dan mencuci. Kebutuhan Air yang dibutuhkan oleh tubuh manusia untuk minum sehari - hari adalah kurang lebih 2 sampai 2,5 liter atau 8- 10 gelas. Macam - macam air yang sering di gunakan sebagai air minum adalah air sungai, air telaga, air sumur dan air waduk. Air minum yang kualitas mikrobiologisnya yang buruk dapat menyebabkan penyakit yang salah satunya yaitu diare. ${ }^{1,2,4}$

Manusia dahulu meminum air dengan cara memasak, tapi karena jaman sudahberubah semua sudah beralih ke air minum isi ulang kemasan galon, bahkan saat ini semakin marak tersedianya air minum isi ulang (refill) yang dipromosikan sebagai air dari sumber mata air pegunungan yang disterilisasi dan dikelola khusus melalui beberapa proses yaitu cholorinasi, aerasi, filtrasi dan penyinaran dengan ultra violet di depot air isi ulang. ${ }^{1,3}$ Untuk itu diperlukan penyedian air bersih yang secara kuantitas dan kualitas harus memenuhi standar baku mutu air bersih. Lemahnya pengawasan produk makanan dan minuman di Indonesia berdampak terhadap kesehatan konsumen yang memakan dan meminumnya. ${ }^{1,3,7}$

Konsumen air minum dalam kemasan galon tersebut tentu saja membutuhkan alat berupa dispenser. Penggunaan dispenser bisa menyebabkan berkumpulnya bakteri. Risiko pencemaran bakteri ini dapat terjadi baik pada keran bersuhu normal, dingin ataupun panas karena mikroba dapat tumbuh pada suhu dingin/psikrofilik, normal/mesofilik atau panas/termofilik. Dampak pencemaran bakteri dalam dispenser kemungkinan dapat menyebabkan gangguan pencernaan berupa diare yang biasanya terjadi pada orang orang yang

mempunyai daya tahan tubuh rendah, misalnya wisatawan. ${ }^{1}$

Pengadaan air bersih untuk keperluan air minum, harus memenuhi persyaratan yang sudah ditetapkan oleh pemerintah. Air minum yang aman bagi kesehatan apabila memenuhi persyaratan secara fisika, mikrobiologi, kimia, dan radioaktif, namun dari segi kualitasnya, masyarakat masih meragukan karena belum ada informai yang jelas dari segi proses maupun peraturan tentang peredaran dan pengawasannya. Parameter penentuan kualitas air minum secara mikrobiologi bahwa air minum tidak diperbolekan mengandung bakteri Coliform dan Escherichia coli. Jika di dalam $100 \mathrm{ml}$ sampel air didapatkan bakteri Coliform, hal ini memungkinkan terjadinya diare dan gangguan pencernaan lain. Penyakit Diare termasuk penyakit yang menonjol di Sulawesi Utara dan menduduki peringkat 2 dengan jumlah kasus 32.589. Berdasarkan profil kesehatan Kota Manado tahun 2008, jumlah kasus diare sebanyak 3.851 kasus di Kota Manado. ${ }^{1,5-6,8-9}$

Penelitian yang dilakukan oleh Rahayu yang meneliti tentang deteksi adanya bakteri pada air minum dalam kemasan gelon didapati 6 dari 30 sampel tidak mengandung bakteri, sedansgkan 24 sampel terdapat bakteri, dan 3 dari 30 sampel tidak memenuhi syarat untuk dikonsumsi. Pada penelitian yang dilakukan Tombeng dkk di Manado mengenai analisis kualitatif kandungan Escherichia coli dan Coliform pada 3 depot air minum isi ulang di kota Manado didapati semua depot yang diteliti sudah terkontaminasi bakteri Colifrom. ${ }^{1,8}$

Berdasarkan uraian di atas maka peneliti sangat tertarik untuk melakukan penelitian tentang pola bakteri aerob pada dispenser air minum kemasan galon pada konsumen di KecamatanTikala.

\section{METODE PENELITIAN}

Penelitian yang dilakukan bersifat deksriptif prospektif. Penelitian ini dilakukan dari bulan Desember 2013 sampai Januari 2014. Sampel pada penelitian ini adalah 20 dispenser air minum di kecamatan Tikala kota Manado. Pengelolaan sampel dilakukan di Laboratorium Mikrobiologi Fakultas Kedokteran Universitas Sam Ratulangi. 


\section{HASIL PENELITIAN}

Penelitian ini di lakukan di Laboratorium Mikrobiologi Fakultas Kedokteran Universitas Sam Ratulangi Manado menunjukkan dari 20 sampel air minum kemasan galon pada dispenser di Kecamatan Tikala terdapat pertumbuhan sebesar 17 sampel (85\%) dan yang tidak menunjukkan adanya pertumbuhan sebesar 3 sampel (15\%).

Tabel 1. Distribusi Sampel Berdasarkan Pertumbuhan Kultur Kuman

\begin{tabular}{lcc}
\hline Hasil kultur & $\begin{array}{l}\text { Jumlah } \\
\text { sampel }\end{array}$ & $\%$ \\
\hline $\begin{array}{l}\text { Ada pertumbuhan } \\
\text { Tidak ada } \\
\text { pertumbuhan }\end{array}$ & 17 & 85 \\
\hline Total & 3 & 15 \\
\hline
\end{tabular}

Berdasarkan Tabel yang disajikan dapat dilihat jumlah sampel yang ada pertumbuhan sebanyak 17 sampel dan tidak ada pertumbuhan sebanyak 3 sampel.

Tabel 2. Hasil Pengecatan Bakteri Gram

\begin{tabular}{lcc}
\hline Bakteri & $\begin{array}{c}\text { Jumlah } \\
\text { sampel }\end{array}$ & $\%$ \\
\hline Gram positif & 3 & 18 \\
Gram negatif & 5 & 29 \\
Gram positif & 9 & 53 \\
dan negatif & & 100
\end{tabular}

Pada Tabel 2 menunjukan hasil pewarnaan gram positif dan negatif pada 20 sampel dimana bakteri gram negatif di temukan pada semua sampel yaitu 5 sampel (29\%), dan bakteri gram positif sebanyak 3 sampel (18\%) dan terdapat pada sampel kedua bakteri gram negatif dan positif sebanyak 9 sampel ( 53\%).

\section{BAHASAN}

Hasil identifikasi bakteri ditemukan 9 spesies bakteriyaitu Bacillus subtilis sebesar 9 sampel (27,27\%), Proteus Vulgaris sebesar 5 sampel (16,66\%), Serratia Rubidaea sebesar 5 sampel ( 16,66\%), Escherchia coli sebesar 2 sampel (6,66\%), Enterobacter cloacae sebesar 2 sampel (6,66\%), Streptococcus spp sebesar 2 sampel (6,66\%), Diplococcus gram negatif sebesar 2 sampel (6,66\%), Providencia stuartii sebesar 2 sampel (6,66\%), dan bakteri Pseudomonas sebesar 1 sampel (3,38\%).

Tabel 3. Hasil biakan kuman pada dispenser air minum kemasan galon Kecamatan Tikala

\begin{tabular}{lcc}
\hline Bakteri & Jumlah & $\%$ \\
\hline Bacillus subtilis & 9 & 30 \\
Proteus vulgaris & 5 & 16,66 \\
Serratiarubidaea & 5 & 16,66 \\
Escherichia coli & 2 & 6,66 \\
Streptococcus spp. & 2 & 6,66 \\
Diplococcus gram negatif & 2 & 6,66 \\
Providencia Stuartii & 2 & 6,66 \\
Enterobacter cloacae & 2 & 6,66 \\
Pseudomonas spp & 1 & 3,38 \\
\hline Total & 30 & 100 \\
\hline
\end{tabular}

Tabel 3 menunjukkan hasil biakan bakteri dari air minum isi ulang kemasan galon pada dispenser di Kecamatan Tikala dimana bakteri Bacillus subtilis sebesar 9 sampel (27,27\%), Proteus vulgaris 5 sampel (16,66\%), Serratia rubidaea 5 sampel (16,66\%), Escherchia coli 2 sampel (6,66\%), Enterobacter cloacae 2 sampel (6,66\%), Streptococcus spp 2 sampel (6,66\%), Diplococcusgram negatif 2 sampel (6,66\%), Providencia stuartii 2 sampel (6,66\%), dan bakteri Pseudomonas 1 sampel (3,33\%).

Pada penelitian Rahayu yang mendeteksi adanya bakteri pada air minum dalam kemasan galon didapati 6 dari 30 sampel tidak mengandung bakteri, sedangkan 24 sampel terdapat bakteri, dan 3 dari 30 sampel tidak memenuhi syarat untuk dikonsumsi. ${ }^{1}$ Pada penelitian Tombeng dkk di Manado mengenai analisis kualitatif kandungan Escherichia coli dan Coliform pada 3 depot air minum isi ulang di kota Manado didapati semua depot sudah terkontaminasi bakteri Colifrom. ${ }^{8}$ Penelitian Rahayu memperlihatkan hasil yang sama yaitu 3 sampel tidak ada pertumbuhan bakteri sedangkan pada penelitian Rahayu didapati 6 sampel tidak ada pertumbuhan bakteri. 
Berdasarkan hasil penelitian pola bakteri aerob pada dispenser air minum isi ulang kemasan galon pada konsumen di Kecamatan Tikala Periode Desember 2013-Januari 2014 maka dapat disimpulkan sebagai berikut :

1. Pemeriksaan kuman pada 20 sampel air yang diperiksa, ditemukan 17 sampel yang menunjukkan pertumbuhan bakteri, terbanyak campuran bakteri gram positif dan negatif.

2. Bakteri yang paling banyak ditemukan yaitu Bacillus subtilis.

\section{DAFTAR PUSTAKA}

1. Rahayu A. Deteksi Adanya Bakteri Pada Air Minum Dalam Kemasan Galon. Dosen Fakultas Kedokteran Wijaya Kusuma Surabaya. 2010.p 1-2,5-6

2. Hidayanti AM, Yusrin. Pengaruh lama waktu simpan pada suhu ruang (2729o) terhadap kadar zat organik pada air minum isi ulang. Jurnal Fakultas Ilmu Keperawatan dan kesehatan Universitas Muhammadiyah Semarang. 2010. p. 50

3. Hardyanti N, Fitri ND. Studi Evaluasi Instalasi Pengolohan Air Bersih Untuk Kebutuhan Domestik dan Non Domestik (Studi Kasus Perusahan Tekstil Bawen Kabupaten Semarang). Program Studi Teknik Lingkungan FT Undip. Jl. Prof. H. Sudarto, SH Tembalang Semarang. 2002.Vol 1 No 1;9;06 p. 37

4. Wandrivel $R$, Suharti $N$, Lestari $Y$. Kualitas Air Minum Yang Diproduksi
Di Depot Air Minum Isi Ulang Di Kecamatan Bungus Padang Berdasarkan Persyaratan Mikrobiologi. Jurnal Kesehatan Andalas. Vol. 1, No.3. 2012.p.130

5. Keputusan Menteri Kesehatan Republik Indonesia No 492/Menkes/per/IV/2010 Tentang Syarat Syarat dan Pengawasan Kualitas Air Minum.

6. Dinas Kesehatan Provinsi Sulawesi Utara Balai Data, Surveilans dan Sistem Informasi Kesehatan. Profil Kesehatan Provinsi Sulawesi Utara 2008. [cited at 2013 November 10]. Available from: http://www.depkes.go.id/downloads/pr ofil/prov_sulut_2008.pdf

7. Suprihatin B, Adriyani R. Higiene Sanitasi Depot Air Minum Isi Ulang Di Kecamatan Tanjung Redep Kabupaten Berbau Kalimantan Timur. Departemen Kesehatan Lingkungan Fakultas Kesehatan Masyarakat Unair. Dinas Kesehatan Kabupaten Berbau Propinsi Kalimantan Timur. 2008.p. 81

8. Tombeng RB, Polii B, Sinolungan S. Analisis Kualitatif Kandungan Escherichia coli dan Coliform Pada 3 Depot Air Minum Isi Ulang Di Kota Manado. Jurnal Fakultas Kesehatan Masyarakat Universitas Sam Ratulangi. 2013.

9. Radji M, Oktavia H, Suryadi H. Pemeriksaan Bakteriologis Air Minum Isi Ulang Di Beberapa Depot Air Minum Isi Ulang di Daerah Lenteng Agung dan Srengseng Sawah Jakarta Selatan. Majalah Ilmu Kefarmasian. Vol. 5 No. 2 Agustus 2008. 